Article

\title{
New Urbanism in the New Urban Agenda: Threads of an Unfinished Reformation
}

\author{
Michael W. Mehaffy * and Tigran Haas \\ School of Architecture and the Built Environment, KTH Royal Institute of Technology, 11428 Stockholm, Sweden; \\ E-Mails: mmehaffy@kth.se (M.W.M.), tigran.haas@abe.kth.se (T.H.) \\ * Corresponding author
}

Submitted: 16 May 2020 | Accepted: 20 August 2020 | Published: 22 December 2020

\begin{abstract}
We present evidence that New Urbanism, defined as a set of normative urban characteristics codified in the 1996 Charter of the New Urbanism, reached a seminal moment-in mission if not in name-with the 2016 New Urban Agenda, a landmark document adopted by acclamation by all 193 member states of the United Nations. We compare the two documents and find key parallels between them (including mix of uses, walkable multi-modal streets, buildings defining public space, mix of building ages and heritage patterns, co-production of the city by the citizens, and understanding of the city as an evolutionary self-organizing structure). Both documents also reveal striking contrasts with the highly influential 20th century Athens Charter, from 1933, developed by the Congrès Internationaux d'Architecture Moderne. Yet, both newer documents also still face formidable barriers to implementation, and, as we argue, each faces similar challenges in formulating effective alternatives to business as usual. We trace this history up to the present day, and the necessary requirements for what we conclude is an 'unfinished reformation' ahead.
\end{abstract}

\section{Keywords}

Athens Charter; Charter of the New Urbanism; New Urban Agenda; new urbanism; sustainable urbanism

\section{Issue}

This article is part of the issue "New Urbanism: From Exception to Norm-The Evolution of a Global Movement" edited by Susan Moore (University College London, UK) and Dan Trudeau (Macalester College, USA).

(C) 2020 by the authors; licensee Cogitatio (Lisbon, Portugal). This article is licensed under a Creative Commons Attribution 4.0 International License (CC BY).

\section{Introduction}

The New Urban Agenda-the outcome document of the United Nations' (UN) 2016 Habitat III conference on housing and sustainable urban development-was subsequently adopted by acclamation by all 193 member countries of the UN (UN, 2016). As such, it stands as the de facto charter of a global movement to address the challenges and opportunities of urbanism in the present day and beyond.

Less well recognized is that many of the elements of the document incorporate concepts earlier advanced in the 1996 Charter of the New Urbanism. As we discuss herein, a number of these concepts had antecedents in earlier publications, but none previously brought them together into a single widely disseminated char- ter of an identifiable global (though US-originated) movement. As such, the adoption of the New Urban Agenda stands as testimony to the pervasive status of these New Urbanist concepts, by any other name, and further supports claims of the increasing mainstream status of New Urbanism in addressing the challenges of contemporary urban development.

Both documents also stand in telling contrast to an earlier seminal document, the 1933 Athens Charter, a landmark of modern urban planning published by the architect Le Corbusier in 1943 on behalf of the Congrès Internationaux d'Architecture Moderne (CIAM; Sennett, Burdett, Sassen, \& Clos, 2018). The Charter of the New Urbanism in particular aims to deliberately reverse key tenets of the Athens Charter, while at the same time building on its similar format (Moule, 2002). 
Here we explore the substantive relationships between the three documents, their background contexts and theories of city form, and the implications for New Urbanism in particular as an increasingly mainstream global movement. We then turn our attention to the implementation issues faced by the two more recent documents, and what they reveal about the remaining and formidable challenges of implementation.

\section{Historical Development of the Athens Charter, the Charter of the New Urbanism, and New Urban Agenda}

What we today refer to as the '1933 Athens Charter' was in fact written by Le Corbusier and published in French ten years later (subsequently translated to English, see Le Corbusier, 1973). Harvard's Jose Luis Sert, a colleague of Le Corbusier in the CIAM, also published a similar text in English, Can Our Cities Survive? (Sert, 1942). Both documents reflected key ideas discussed at a seminal CIAM meeting that did in fact occur ten years earlier. This famous meeting was held on a cruise from Marseilles to Athens (hence 'Athens Charter'). Many key concepts of Le Corbusier's text (and Sert's) had already been developed in a previous series of CIAM conferences, culminating in this fourth plenary conference of 1933 (Gold, 1998).

In fact, as has been demonstrated by Gold (1998), the outcome in 1933 was merely a series of discussion points, drafts, and drawings, not an agreed-upon 'charter.' Le Corbusier later developed his own list of 95 points-perhaps as a nod to Martin Luther's 95 Theses-covering his and his colleagues' exhaustive proposals for the planning of modern cities.

One of the most significant issues of divergence, according to Gold (1998), was Le Corbusier's more restrictive definition of 'functionalism,' in contrast to the more generous definition preferred by his colleagues. For them, the term included not only physical 'functions' but also intellectual, emotional, and spiritual ones as well. Le Corbusier was far more interested in responding to the dictates of that era's standardized production, and hence his idea of 'functionalism' was more mechanically focused (Gold, 1998, p. 228). This technical agenda also ran closely with a political agenda for Le Corbusier: to develop a consensus between disparate CIAM parties that included unionists, collectivists, Italian fascists, technical experts, and others (Holston, 1989). In the end, it was Le Corbusier's formulation of functionalism-and of the guiding ideas of urbanisation-that became the authoritative formulation known as the '1933 Athens Charter.' In turn, it was this document that exercised a profound effect upon the patterns of urbanisation for much of the century to come.

In this sense, Le Corbusier's goals were almost perfectly aligned with the dictates of early 20th century industrial technology, and almost perfectly poised to move into successful implementation. Indeed, that implementation happened most powerfully in the US, where Le Corbusier's CIAM colleague Walter Gropius became dean of Harvard's Graduate School of Design, their associate Mies van der Rohe became the head of the architecture programs at both the Art Institute of Chicago and Armour Institute of Technology, and they and others began to play an increasingly prominent role in shaping the emerging urbanisation policy of that generation. In fact, Le Corbusier's urban vision for the post-war future captivated a global audience at the 1939 World's Fair, in a design by his admirer Norman Bel Geddes for an exhibit by General Motors called Futurama.

Thus, the CIAM vision did in fact become the model for much of the post-war development in the US and increasingly around the world: the ubiquitous freeways, superblocks, and towers set back from streets. The model also features uses segregated by function, dominance of mechanical modes of travel, and replacement of 'obsolete' buildings and neighbourhoods with gleaming new structures designed to precise technical specifications by technical experts. This was a functionalism in Le Corbusier's definition of the term: The city would function like a precise machine, precisely combining separate mechanical elements.

That this scheme was effectively implemented is evidenced by the vast stretches of urban structure created profitably according to this model, and still being created in many places today (Figure 1). However, what was overlooked by the CIAM model was the web of human interactions and relationships that formed within the network of public and private spaces. The Athens Charter model fatefully separated the street from the building, as well as the home from work and school, disrupting the normal course and social mixing of everyday life. The consequences of this fateful segregation were evident as this experiment went forward in the 1950s and 1960s.

\subsection{The Era of Reform Begins: The 1960s and beyond}

As a result of the evident weaknesses of the Athens Charter and Le Corbusier's vision in particular, a number of reformers began to voice their criticisms beginning around 1960. In that year, the CIAM breakaway group known as Team 10 embraced a more 'structuralist' understanding of architecture as a setting for human life and culture. This was in strong contrast to Le Corbusier's more 'rationalist' approach to urban planning, which, they argued, ignored the patterns of life and the complex relationships of inhabitants (van Eyck, 1954). One of the most prominent structuralist advocates was (and is) the Dutch architect John Habraken, an early pioneer of the co-called 'participation movement' in which users were seen as active co-creators of the urban environment (Habraken, 2019).

Another highly influential critic around that time was the journalist and urbanist Jane Jacobs, whose landmark book The Death and Life of Great American Cities (1961) became widely influential, notably for both the later New 

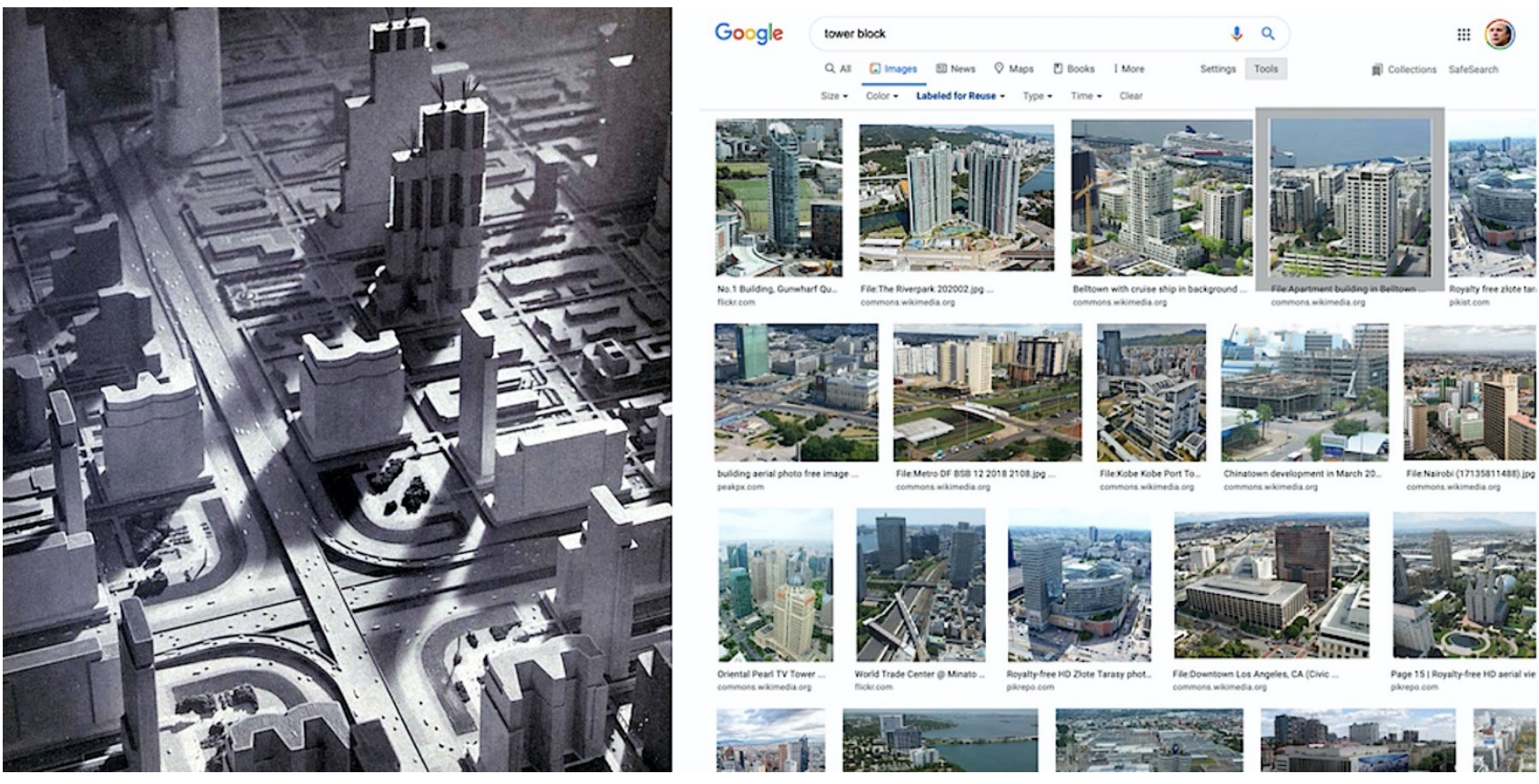

Figure 1. A model built by designer Norman Bel Geddes for a Shell Oil advertisement (left) shows many of the principles of the Athens Charter: zoning by use, segregation of automobiles onto functionally classified roadways, buildings floating loosely within superblock systems, replacement of historic patterns, and the city as technically determined creation. Barely a half-century later, this model of urbanism had become ubiquitous the world over and remains so-as this Google image search demonstrates (right). Source: Google Search ('labelled for reuse' filter on).

Urbanists and the framers of the New Urban Agenda (Mehaffy, 2017). Her book attacked the functional segregation of the Athens Charter as well as the Garden City movement before it. Her criticism of Le Corbusier's ideas in particular was withering:

His conception, as an architectural work, had a dazzling clarity, simplicity, and harmony. It was so orderly, so visible, so easy to understand. It said everything in a flash, like a good advertisement....But as to how the city works, it tells, like the Garden City, nothing but lies. (Jacobs, 1961, p. 23)

More than a criticism, Jacobs' book was a passionate defence of the under-appreciated human connections and interactive processes occurring within the urban places she observed. She saw these as under great threat in the era of 'urban renewal,' wherein the older, messier parts of cities were to be replaced with rationally planned environments following the recipe of the Athens Charter. But instead of the Athens Charter's machinelike functional segregation, Jacobs advocated diversity and mixing. Instead of what she called "project land oozings" and "loose sprawls" around Le Corbusier's model of towers in a park (Jacobs, 1961), she argued for well-formed streetscapes and buildings forming coherent public space systems. Instead of 'projects' on superblocks, cut off from the wider city by dead zones that she termed "border vacuums" (Jacobs, 1961), she argued for a continuous evolving network of interconnected urbanism.
This network conception of cities came to be a major theme of Jacobs' work and the work of many others to follow-including, as we will see, the New Urbanists and the creators of the New Urban Agenda. In this new model, the city was no longer a static work of art and engineering created by rational methods, but instead was a dynamic place of social mixing, interaction, cocreation, and self-organization. Jacobs' later work on urban economics emphasised the economic processes that occurred through spatial network interactions and "knowledge spillovers" (Jacobs, 1969). Cities, by their structures and their processes, generate the capacity for creative interaction and human (including economic) development, she argued. They do this through the webnetworks that form and transform between people and resources. All of these social, economic, and resource networks are rooted in a city's physical networks of public and private spaces, together with their connections. These may be physical connections or other kinds of connections (e.g., data), but all of them ultimately are grounded in the physical framework formed by a city's networks of public space. Get that wrong, Jacobs said, and your city will be in trouble.

A similar focus on networks in urban relationships and their spatial forms came from the architect Christopher Alexander, whose Cambridge training included mathematics (Mehaffy, 2017). His widely influential 1965 paper "A City is Not a Tree" argued that the elements of a city were not optimally connected through the rationally segregated, hierarchical (tree-like) conception of the Athens Charter. Rather, the best cities con- 
tained 'semi-lattices,' web-network relationships that could not be neatly sorted into hierarchical schemes. This was not a defect of cities, or a form of disorder, but on the contrary, a deeper form of order:

It must be emphasized, lest the orderly mind shrink in horror from anything that is not clearly articulated and categorized in tree form, that the idea of overlap, ambiguity, multiplicity of aspect and the semilattice are not less orderly than the rigid tree, but more so. They represent a thicker, tougher, more subtle and more complex view of structure. (Alexander, $1965 / 2015$, p. 16)

Alexander later argued that these overlapping webnetwork relationships formed 'patterns' between people and their environments, which evolved and could be shared much like a language-hence they formed, as a later book proposed, a shareable 'pattern language' (Alexander et al., 1977). Among these important patterns were a number that defied the Athens Charter's neat scheme of functional segregation by use and mode: "Scattered Work," "Web of Shopping," "Street Cafe," "Building Fronts," "Private Terrace on the Street," and so on (Alexander et al., 1977). These and other patterns also described a more traditional urban fabric of mixed buildings framing the edges of mixed streets and other public spaces. The book also emphasized, through its very design and aim, the co-production of the city by users who might participate in applying these or other patterns, and the evolution of city form through these small and large acts of accretion. This was a city evolving and self-organizing over time, retaining many existing patterns and structures, while continuously adding to and transforming many of them.

\subsection{The Emergence of 'the New Urbanism'}

By the 1980s, a number of practitioners had begun to apply Jacobs' and Alexander's ideas in the field. Architects Andrés Duany and Elizabeth Plater-Zyberk, two of the most energetic figures of what was to become known as the New Urbanism movement, designed and participated in the construction of Seaside, a 1980s Florida resort town that broke early from the Athens Charter logic. Duany later referred to Alexander as "one of the most influential people who has ever been in the design world. His influence on us, operationally, has been enormous" (Project for Public Spaces, 2008). At the same time, Jacobs' ideas on mixed use, walkable small blocks, diversity of buildings and compactness of urban form also greatly influenced the emerging New Urbanist practitioners and theorists, who frequently honoured her by name (Talen, 2005).

What we now know as New Urbanism was first developed as a set of principles created at a conference convened in 1991 by California's Local Government Commission, which had been set up by former Governor
Jerry Brown. The reformist group of architects and planners (including Duany and Plater-Zyberk) produced the "Ahwahnee Principles for Resource-Efficient Communities," named for the lodge in California's Yosemite National Park where the meeting was held. Like Jacobs and Alexander, the group's document promoted mixed use, mixed transit, fine-grained streets, public spaces defined by buildings, and involvement of citizens in creating their environments, all in stark contrast with the Athens Charter.

Energized by the effort and by a companion book titled The New Urbanism by Peter Katz (1993), the group later formed a non-profit organization and developed its detailed 'Charter of the New Urbanism.' The document includes 27 principles sorted by scale (from the regional to the building) following a preamble describing its reformist intent:

We advocate the restructuring of public policy and development practices to support the following principles: neighbourhoods should be diverse in use and population; communities should be designed for the pedestrian and transit as well as the car; cities and towns should be shaped by physically defined and universally accessible public spaces and community institutions; urban places should be framed by architecture and landscape design that celebrate local history, climate, ecology, and building practice. (Congress for the New Urbanism [CNU], 2020, Preamble)

\subsection{The Development of the New Urban Agenda}

In 1976, the UN began the first of a series of high-level conferences on urbanisation known as the Habitat conferences. Habitat I, held in Vancouver, Canada, established goals for improving the quality of urbanisation and its human outcomes, particularly for rural areas. Habitat II, in Istanbul, Turkey in 1996, aimed to address the environmental issues surrounding urbanisation. Habitat III, in Quito, Ecuador in 2016, focused upon trends of rapid urbanisation, quality of life, inclusion, 'cities for all,' and the goal of articulating a 'New Urban Agenda' for better quality urban development (UN-Habitat, 2020).

The New Urban Agenda text emerged from a number of conferences, regional and thematic meetings, policy papers and issue papers, and preparatory committee meetings, beginning in 2013. A number of prominent New Urbanists participated in these events, notably the 'Future of Places' conferences featuring the first UN-Habitat 'Urban Thinkers' Campus,' attended by Andrés Duany, Elizabeth Plater-Zyberk, Doug Kelbaugh, Charles Bohl, and Victor Dover (Future of Places, 2020). A 'zero draft' of the New Urban Agenda was released in May 2016 and subsequently edited. The UN General Assembly agreed on the final draft in September 2016, and it was adopted by acclamation in December 2016 (UN-Habitat, 2020). 
Like the Charter of the New Urbanism, the New Urban Agenda calls for deep reform of urban planning and design practices:

We commit ourselves to working towards an urban paradigm shift for a New Urban Agenda that will: (a) Readdress the way we plan, finance, develop, govern and manage cities and human settlements, recognizing sustainable urban and territorial development as essential to the achievement of sustainable development and prosperity for all. (UN-Habitat, 2020)

As we will discuss below, the New Urban Agenda also reflects a number of the shifts in thinking about the nature of cities and the challenges of goodquality urbanisation that occurred form the time of the Athens Charter.

\section{From the 1996 Charter of the New Urbanism to the 2016 New Urban Agenda: Maturation of a New Global Movement}

When we search for parallels relating to urban form in the two more recent documents, we readily find significant correspondences. The New Urban Agenda calls for "urban spatial frameworks" that are "well-connected" and featuring "compactness and density" (UN, 2016, para. 51-52). The Charter of the New Urbanism likewise calls for "interconnected networks of streets" that offer "supportive physical frameworks" and urban patterns that are "compact" (CNU, 2020, Preamble). The New Urban Agenda calls for "polycentrism" (UN, 2016, para. 51,98$)$ while the Charter of the New Urbanism articulates "multiple centers that are cities, towns, and villages" (CNU, 1996, para. 1). Most notably, both documents stipulate 'mixed use' in contrast to the segregation of uses (residential, commercial, civic, etc.) that was common in earlier 20th century planning.

Another striking parallel is in the key role of open and accessible public space, which both documents highlight, with the CNU Charter arguing that "cities and towns should be shaped by physically defined and universally accessible public spaces" including "interconnected networks of streets" (CNU, 1996, Preamble) while the New Urban Agenda lists the goal of "well-connected and welldistributed networks of open, multipurpose, safe, inclusive, accessible, green and quality public spaces," "including streets" (UN, 2016, para. 67).

Common to both documents are provisions for multimodal streets for pedestrians, bicycles, transit, and cars. Communities in the CNU Charter will be "designed for the pedestrian and transit as well as the car" (CNU, 1996, Preamble) and "transit, pedestrian, and bicycle systems should maximize access and mobility throughout the region while reducing dependence upon the automobile" (CNU, 1996, para. 8). The New Urban Agenda sets the goal of "safe, inclusive, accessible, green and quality public spaces, including streets, sidewalks and cycling lanes" that are "multifunctional areas for social interaction and inclusion, human health and well-being, economic exchange and cultural expression" (UN, 2016, para. 37).

In both documents, buildings play a supportive role in defining and connecting to streets as key public spaces. The Charter of the New Urbanism declares that "a primary task of all urban architecture and landscape design is the physical definition of streets and public spaces as places of shared use" (CNU, 1996, para. 19). The New Urban Agenda calls for "measures that allow for the best possible commercial use of street-level floors, fostering both formal and informal local markets and commerce, as well as not-for-profit community initiatives, bringing people into public spaces and promoting walkability and cycling with the goal of improving health and well-being" (UN, 2016, para. 100).

Another notable parallel occurs with the topic of urban heritage. In both cases, heritage is seen not as a mere cultural relic but as an active resource providing patterns and solutions for modern challenges, including sustainable development. The New Urban Agenda calls for "prioritizing renewal, regeneration and retrofitting" (UN, 2016, para. 97) while the Charter of the New Urbanism places a priority on "reconfiguration" of existing neighbourhoods, and "preservation and renewal" (CNU, 1996, Preamble). The CNU Charter decries "the erosion of society's built heritage" (CNU, 1996, Preamble) while the New Urban Agenda calls for "leveraging of cultural heritage for sustainable urban development" (UN, 2016, para. 38, 125).

Both documents also place an emphasis on empowerment and capacity-building of excluded populations, with the New Urban Agenda advancing "equal rights and opportunities" (UN, 2016, para. 12) and "socioeconomic and cultural diversity" (UN, 2016, para. 14) while the Charter of the New Urbanism opposes "increasing separation by race and income" and argues instead that "neighbourhoods should be diverse in use and population" (CNU, 1996, Preamble). Both emphasize the importance of safety and security while also maintaining openness to all. The CNU Charter argues that "the design of streets and buildings should reinforce safe environments, but not at the expense of accessibility and openness" (CNU, 1996, para. 21) while the New Urban Agenda proposes "public spaces that...foster social cohesion, inclusion and safety" (UN, 2016, para. 25). Both also emphasize public involvement, with the CNU Charter committing to "citizen-based participatory planning and design" (CNU, 1996, Preamble) while the New Urban Agenda proposes "enabling the participation and engagement of communities and relevant stakeholders in the planning and implementation" and "supporting the social production of habitat" (UN, 2016, para. 31).

Lastly, both documents see design within the larger context of an evolving and self-organizing urban system. The CNU Charter argues that the role of design is to provide "a coherent and supportive physical frame- 
work" for the sustained growth of "economic vitality, community stability and environmental health" (CNU, 1996, Preamble) and that "architecture and landscape design should grow from local climate, topography, history, and building practice" (CNU, 1996, para. 24). The New Urban Agenda speaks of "the evolving needs of persons and communities" and the role of "incremental housing and self-build schemes" among other evolving aspects of the city (UN, 2016, para. 107). Clearly, design has an important role, but one that is continuously engaged with the challenges of the city at many scales of space and time.

More broadly, both documents express an urgency in the unacceptable status quo and propose an aggressive reform agenda to counter it. The Charter of the New Urbanism starts out by proclaiming:

The Congress for the New Urbanism views disinvestment in central cities, the spread of placeless sprawl, increasing separation by race and income, environmental deterioration, loss of agricultural lands and wilderness, and the erosion of society's built heritage as one interrelated community-building challenge. (CNU, 1996, Preamble)

It then lays out five reformist preamble paragraphs, followed by twenty-seven detailed principles of revitalized or 'new' urbanism, grouped at regional, neighbourhood, and building scales.

The Charter of the New Urbanism is careful to qualify the importance of urbanism in meeting the challenges of the future, but at the same time, it offers a vision of cities and towns as essential physical frameworks for human well-being: "We recognize that physical solutions by themselves will not solve social and economic problems, but neither can economic vitality, community stability, and environmental health be sustained without a coherent and supportive physical framework" (CNU, 1996, Preamble).

Taking a similarly reformist tone, the New Urban Agenda calls for "readdressing the way cities and human settlements are planned, designed, financed, developed, governed and managed" (UN, 2016, para. 5) to achieve the "sustainable urban development" (UN, 2016, para. 9) and "cities for all" (UN, 2016, para. 11). These reforms are necessary because:

We are still far from adequately addressing...existing and emerging challenges, and there is a need to take advantage of the opportunities presented by urbanisation as an engine of sustained and inclusive economic growth, social and cultural development, and environmental protection, and of its potential contributions to the achievement of transformative and sustainable development. (UN, 2016, para. 4)

In both documents, then, urbanism offers powerful opportunities to humanity-but our current methods are inadequate, and in urgent need of the structural reforms specified by both.

\section{Comparing All Three Documents: Tracing the Threads of a Century of Urban Thinking}

Both the New Urban Agenda and the Charter of the New Urbanism stand in striking contrast to the Athens Charter, particularly on six seminal topics:

- Mix of uses (in place of functional segregation of uses);

- Walkable multi-modal streets (in place of functional segregation of streets and travel);

- Buildings defining public space (in place of open patterns of buildings and vegetation);

- Mix of building ages and heritage patterns (in place of demolition of most historic buildings);

- Co-production of the city by the citizens (in place of city creation solely by technical experts);

- The city as an evolutionary self-organizing structure (in place of the city as a static end state of design).

These specific points are part of a deeper centurylong change in the model of urbanism and urbanisation, gradually embracing its open, incremental, and informal aspects, and the emergent characteristic that Jane Jacobs (1961) referred to as 'organised complexity.' Yet this transformation has not yet been fully made, according to Joan Clos, Secretary-General of Habitat III, writing with a group of co-authors including the sociologists Richard Sennett and Saskia Sassen:

Many of the 94 recommendations of the 1933 Athens Charter still determine the generic forms and physical organisation of 21 st century city. (Sennett et al., 2018, p. 3)

For Clos and his co-authors, this is a problem: "The patterns of urbanisation today require a re-framing of the discourse and practice of planning, one that questions the very tenets of the Athens Charter and challenges the value of anachronistic 'bottom-up vs top-down' models, so heavily rooted in western urbanism" (Sennett et al., 2018, p. 114). The New Urban Agenda begins this project, they say. However:

More work is needed to complement the New Urban Agenda, helping to mark a paradigm shift away from the rigidity of the technocratic, generic modernist model we have inherited from the Athens Charter towards a more open, malleable and incremental urbanism that recognizes the role of space and place-and how they are shaped by planning and design-in making cities more equitable. (Sennett et al., 2018, p. 66) 
It is also clear that the Charter of the New Urbanism is a rejection of the modernist approach to urban design embodied in the Athens Charter, as one of the founders, Andrés Duany, has stated: "Our ideology is different" (Duany, 1997, p. 48). At the same time, the New Urbanists acknowledge their debt to the modernists, at least in part: "In important ways the Congress for New Urbanism is modelled on CIAM [Congrès Internationaux d'Architecture Moderne, for whom the Athens Charter was written]....Our methodology is the same" (Duany, 1997, p. 48).

The magnitude of the 'paradigm shift' described by Clos and others can readily be observed by comparing the Athens Charter with both the New Urban Agenda and the Charter of the New Urbanism. In place of the 'mixed use' of the two later documents, the Athens Charter states that "zoning is an operation carried out on the city map with the object of assigning every function and every individual to its rightful place" and "by taking account of the key functions-housing, work, recreation-zoning will introduce a measure of order into the urban territory" (Le Corbusier, 1973, para. 15). In place of streets as multi-modal places of shared use, the Athens Charter proposes "a radical separation of pedestrians from mechanized vehicles" (Le Corbusier, 1973, para. 60). In place of buildings aligning to streets as public spaces, it commands that "the alignment of dwellings along transportation routes must be prohibited" (Le Corbusier, 1973, para. 27).

Similarly, heritage is not a candidate for 'renewal' in the Athens Charter, but on the contrary, for destruction, especially in the case of older buildings occupied by the poor: "An elementary knowledge of the principal notions of health and sanitation is sufficient to detect a slum building and to discriminate a clearly unsanitary city block. These blocks must be demolished" (Le Corbusier, 1973, para 36). While a few historic monuments are to be kept as relics, their surrounding historic fabric, characterised as 'slums,' is slated for wholesale demolition: "The destruction of the slums around historic monuments will provide an opportunity to create verdant areas" (Le Corbusier, 1973, para. 69).

The Athens Charter also does not elevate the goal of promoting diversity and social justice as the later documents do, but rather considers these topics in only the limited context of modernisation. While historic preservation is seen in the later documents as a shared public good and a tool of regeneration and opportunity, for the Athens Charter its obstruction of modernization is seen as inherently unjust: "By no means can any narrowminded cult of the past bring about a disregard for the rules of social justice" (Le Corbusier, 1973, para. 67). A second reference comes from the alleged "injustice" of the "arbitrary constraint" of walking, to be liberated by the vehicles of the new machine age: "Arbitrary constraints gave rise to flagrant injustices. Then the age of machinism arose" (Le Corbusier, 1973, para. 6). References to 'diversity' are limited to technical requirements, like those for streets: "Confronted with mecha- nized speeds, the street network seems irrational, lacking in precision, in adaptability, in diversity, and in conformity" (Le Corbusier, 1973, para. 6) Elsewhere, the issue of cultural diversity is defined only as a "biological and psychological constraint" to be overcome with universalizing design solutions: "Finally, the races [sic] of mankind, with their varied religions and philosophies, multiply the diversity of human undertakings, each proposing its own mode of perception and its own reason for being" (Le Corbusier, 1973, para. 3). This is a diversity that is not to be sought and promoted, but rather regarded as a mere pre-existing condition that must inform "the rationale governing the development of cities" (Le Corbusier, 1973, para. 7).

While the later documents see the role of citizens as co-producers of the city with the right of public involvement at many scales, the Athens Charter focuses instead on the role of technocratic specialists: "The principles of modern urbanism, evolved through the labours of innumerable technicians - technicians in the art of building, technicians of health, technicians of social organization...still must be acknowledged by the administrative agencies charged with watching over the destiny of cities" (Le Corbusier, 1973, para. 74). Furthermore, "the program must be based on rigorous analyses carried out by specialists" (Le Corbusier, 1973, para. 86). The public's role is not to co-produce, but on the contrary, to merely "understand, desire, and demand what the specialists have envisaged for it" (Le Corbusier, 1973, para. 91). A top-down agency is to deliver these results: "A political power such as one might wish-clear-sighted, with earnest conviction, and determined to achieve those improved living conditions that have been worked out and set down on paper" (Le Corbusier, 1973, para. 91).

The understanding of change over time within the city is also remarkably different in the Athens Charter. Whereas the newer documents describe the dynamic, evolutionary nature of the city, the Athens Charter has a clear focus on the city as a static work fixed in time by a static plan: "Plans will determine the structure of each of the sectors allocated to the four key functions and they will also determine their respective locations within the whole" (Le Corbusier, 1973, para. 78). These are rigid and not to be altered: "Inviolable rules will guarantee the inhabitants good homes, comfortable working conditions, and the enjoyment of leisure. The soul of the city will be brought to life by the clarity of the plan" (Le Corbusier, 1973, para. 86).

These six topics, then - the zoning of urban elements, the design of streets, the orientation of buildings, the treatment of historic structures and patterns, the role of specialists in relation to citizens, and the accommodation of change and process-are perhaps the most salient points of agreement between the New Urban Agenda and the Charter of the New Urbanism, and the most striking points of contrast of both with the earlier Athens Charter (Table 1). These differences are well illustrated in a 1948 drawing by Adolf Bayer (Figure 2). 
Table 1. Comparison of the three documents (Athens Charter, Charter of the New Urbanism, and New Urban Agenda) on six normative topics of urbanism.

\begin{tabular}{|c|c|c|c|}
\hline Topic & Athens Charter (1933) & $\begin{array}{l}\text { Charter of the New } \\
\text { Urbanism (1996) }\end{array}$ & New Urban Agenda (2016) \\
\hline $\begin{array}{l}\text { 1. Zoning of urban } \\
\text { elements }\end{array}$ & $\begin{array}{l}\text { Uses are segregated } \\
\text { according to function } \\
\text { (residential, commercial, } \\
\text { civic, etc.) }\end{array}$ & $\begin{array}{l}\text { Mixed uses are encouraged } \\
\text { while regulation focuses on } \\
\text { form }\end{array}$ & $\begin{array}{l}\text { Mixed uses are encouraged } \\
\text { while regulation focuses on } \\
\text { form }\end{array}$ \\
\hline
\end{tabular}

\section{Design of streets}

3. Orientation of buildings

4. Treatment of historic structures and patterns

\begin{abstract}
All streets are functionally segregated by vehicle speed, and pedestrians are prohibited
\end{abstract}

\section{Buildings are removed from edges of streets into 'superblocks'}

\section{Most historic structures are demolished, while only a few representative monuments are retained; most traditional patterns are rejected as not 'of our time'}

The city is solely a creation of centralized specialists (economic, political, technical); citizens are passive beneficiaries

The city is a technically determined structure designed statically to meet fixed human needs
Urban streets are places of multi-modal transportation and public spaces, welcoming pedestrians

Buildings align with and enclose streets and other public spaces

Both tangible (buildings, monuments) and intangible (knowledge, patterns) heritage is conserved and re-used, often synthesized with new technologies and approaches

The city is socially produced by many actors at many levels, through the empowerment of many diverse citizens and institutions

The city is a dynamic, evolutionary, partly self-organizing system whose design is continually adaptive
Urban streets are places of multi-modal transportation and public spaces, welcoming pedestrians

Buildings align with and enclose streets and other public spaces

Both tangible (buildings, monuments) and intangible (knowledge, patterns) heritage is conserved and re-used, often synthesized with new technologies and approaches

The city is socially produced by many actors at many levels, through the empowerment of many diverse citizens and institutions

The city is a dynamic, evolutionary, partly self-organizing system whose design is continually adaptive

\section{Conclusion: The Daunting Challenge of Implementation}

Neither the Charter of the New Urbanism nor the New Urban Agenda have gone without substantial criticism, certainly, although a full discussion is beyond the scope of this article. However, it has been noted that many of the criticisms of New Urbanism in particular are based on "flawed arguments (with various strains of logical fallacies), unclear conceptual frameworks and inconsistent categories of theoretical thought" (Haas, 2005, p. 11). As Emily Talen $(2000$, p. 335 ) has argued, there is a need to disentangle the normative aspirations of New Urbanism from its failures of implementation, "redirecting their critique of implementation toward the underlying reasons for that failure (which largely lie outside of its normative ideals)." The same could be said for the New
Urban Agenda, whose aspirations-sustainable and just cities and towns with healthy, prosperous populationsare not generally controversial, although the topic of implementation certainly deserves more critical examination (World Economic Forum, 2020). That critical topic will be the focus of our conclusion.

We start by noting that, by comparison, the Athens Charter devoted much more attention to the challenges of implementation than either of the more recent documents-and to date it has been far more successful in actual implementation (for better or worse) than the other two. A number of the Athens Charter' observations on implementation would apply equally to the two new documents, notably that "there are two opposing realities: the scale of the projects to be undertaken urgently for the reorganization of the cities, and the infinitely fragmented state of land ownership" (Le Corbusier, 1973, 


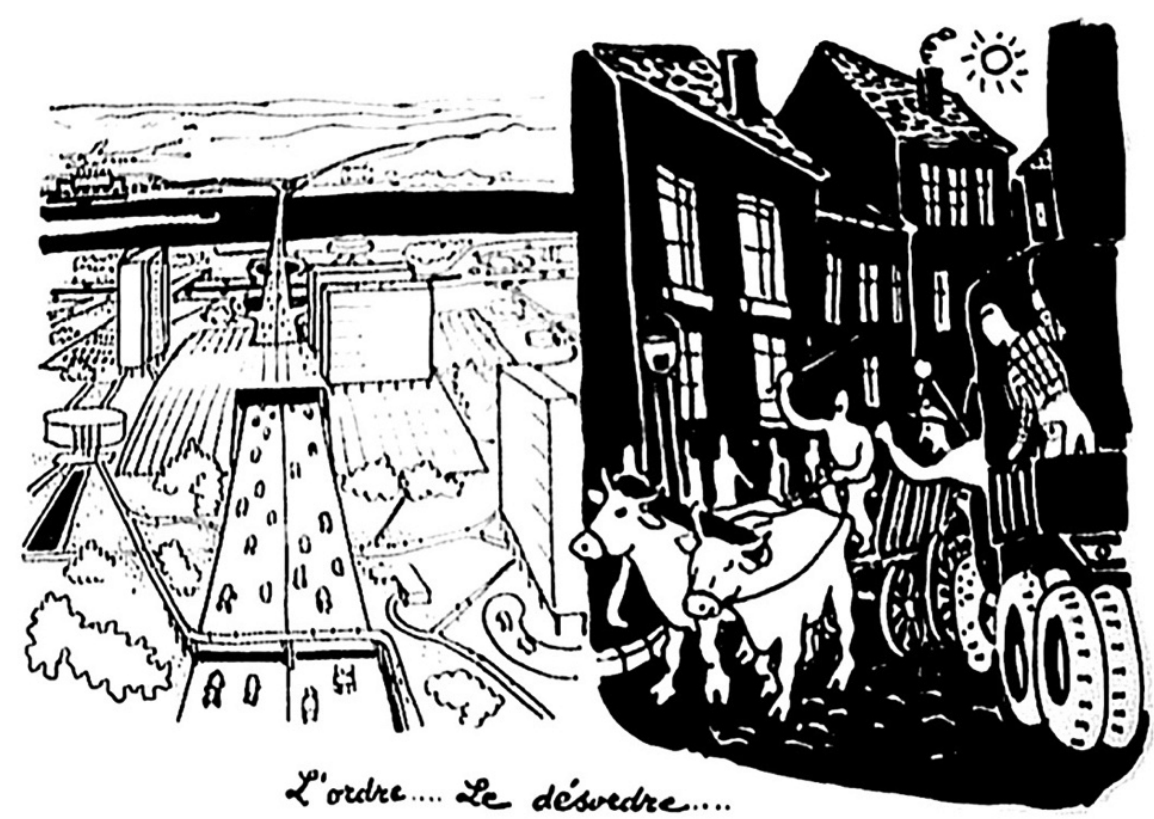

Figure 2. A 1948 drawing by Adolf Bayer shows the striking contrast between the modernist city-'order'-and the traditional city-'disorder.' The traditional city on the right features a mix of uses and modes on walkable streets, buildings defining the edges of public spaces including streets, a mix of buildings and heritage patterns, and an open, self-organizing pattern shaped by many actors, which only seems chaotic. The modernist city on the left, however, features segregated uses, pedestrians segregated from streets, a loose pattern of buildings floating in green space, pristine buildings, and a highly determined, static environment created by technical specialists. Source: Google Images ('labelled for reuse' filter on).

para. 93). The system of delivery gets careful consideration in the Athens Charter, as well as the call for scientific research to address so-called 'lock-in' from outmoded systems: "Sometimes a scientific discovery is enough to upset the equilibrium, to reveal the discord between the administrative system of yesterday and the pressing realities of today" (Le Corbusier, 1973, para. 93).

The Athens Charter also explicitly recognizes the importance of a realistic attitude in exploiting the technological and economic capabilities of the day-also no less true today: "Countless difficulties have harassed people who were unable to gauge accurately the extent of technical transformations and their tremendous repercussions on public and private life" (Le Corbusier, 1973, para. 94). Instead, we must recognize and facilitate "an economic situation that will make it possible to embark upon and pursue building projects which, in certain instances, will be considerable" (Le Corbusier, 1973, para. 91). That is, designers and planners must become active participants in directing technical and economic forces to deliver the results they seek. This is a point that has also been made by some of the founders of the New Urbanism, including Andrés Duany (2004).

The call by Clos and his colleagues for "a more open, malleable and incremental urbanism" must also address the potential conflict, or at least disconnect, between that open and malleable urbanism and "making cities more equitable" (Sennett et al., 2018, p. 66). How can 'open' economic processes be prevented from exacerbating inequality and exclusion? This might be done through mechanisms of connection, empowerment, and capacity-building, of the sort described by, say, Jane Jacobs (1961)-but clearly, more work is needed in this area.

Implementers of the Charter of the New Urbanism have arguably not done enough to address the informal aspects of urbanisation, at a time when, in many parts of the world today, informality is a dominant aspect of urbanisation, and urban inequality is also reaching runaway levels (Mehaffy \& Haas, 2018). That omission was the subject a persistent criticism of New Urbanism by the iconoclastic architect Christopher Alexander, who has long argued instead for more incremental, process-based systems and technologies (Alexander, Schmidt, Hanson, Alexander, \& Mehaffy, 2005). By contrast, the New Urban Agenda does pledge "support to incremental housing and self-build schemes, with special attention to programmes for upgrading slums and informal settlements" (UN-Habitat, 2020, para. 107). Yet in both cases, mechanisms of implementation seem incomplete at best.

Not surprisingly, the Charter of the New Urbanism, created for an organization based in the US, has often been criticised for its Americentric and Eurocentric perspective on urbanisation, at a time that the processes that shape cities are more global than ever before in history. On the other hand, models created in the US have had, and still have, an impact around the world. It follows that organisations that seek to reform those models, like the CNU, can play a particularly important role in working with other global partners to implement reforms. 
More broadly, it must be recognised that the forces that shape cities are only partly affected by planning, policy, or other 'command functions' of government at the state or even the city scale. As Sassen (2010) has written, global inter-city networks of trade and capital flow are increasingly dominant forces. Urban real estate has become an important focus of international capital movement and extraction of surplus value, in some cases marginalizing the power of national governments. Without a global perspective on these dynamics and new global financial tools in response, the implementation of the goals of empowering citizens, promoting diversity, and reducing "separation by race and class" (CNU, 2020, Preamble) is likely to make little progress against the increasingly virulent global phenomena of gentrification, displacement, and segregation.

On the other hand, we are not powerless in the face of financial dynamics, for these are profoundly shaped by taxation policies, technological economies, regulatory structures, and other consciously chosen forms of economic and policy feedback. Jacobs (1961, p. 252), for her part, made a very telling remark: "In creating city success, we humans have created marvels, but we left out feedback." The global transition ahead will require much better feedback systems.

The runaway negative consequences of this lack of healthy regulatory feedback are certainly not absent from the landscape of the US: indeed, they are surging in many US cities. To the extent that New Urbanists helped to re-popularize the urban cores, from Brooklyn to Portland and many other US cities (and by extension, from London to Stockholm to Tokyo to Sydney), they seem to have exacerbated these runaway problems without doing enough to dampen them. In that sense, the 'new urbanisation' advocated by the New Urbanism has perhaps been too much of a good thing.

It is not that walkable mixed-use urbanism in itself is bad, of course-certainly not in relation to its sprawl alternative-or that there is not a real 'agglomeration benefit' to be had from the network effects of city cores, as we have learned from much recent research (see e.g., Batty, 2013; Bettencourt, 2013). The question is how the network effects are engaged (and managed and dampened when necessary) to produce these agglomeration benefits equitably and sustainably, and not as a poorly controlled, uneven, or runaway phenomenon. An important secondary question is how these goals can be achieved and sustained within a sustainable financial and technical system, on a par with the undeniable (if unsustainable) success in implementation of the Athens Charter model.

The first task is to recognise, like a doctor working on a complex medical problem, "the kind of problem a city is," in Jacobs' words (1961, p. 428). In particular, we must better understand (so as to better manage) the social and economic power of urban networks, including their economic dynamism and potential human opportunities (as well as remarkable resource efficiency and com- parative emissions reductions per capita). This was the insight first recognised by Jacobs (1961) and Alexander (1965/2015). These agglomeration benefits include powerful 'knowledge spillover' potentials (Roche, 2019) that illustrate Jacobs' famous remark about 'lowly' sidewalk contacts which are the "small change from which a city's wealth of public life may grow" - and other more literal forms of wealth too, as it now appears (Jacobs, 1961, p. 72).

The problem, from the point of view of network theory, is that it is possible to over-concentrate these networks, and rely too much on what are known in the theory as 'rich club networks.' These clusters of nodes within a network are particularly well-connected to other adjacent nodes, conferring more powerful benefits to that part of the network (the term comes from social networks, and the advantage of 'who you know' within an often exclusive but well-connected sub-network). While there is certainly a benefit to concentrating clusters of talents and smarts-for individuals who are connected, and for the cluster as a whole-those benefits may not spill over to other parts of the network outside the cluster.

This lopsided distribution is not only unjust; it places a drag on the performance of the network as a whole. As Bettencourt (2013) and others have argued, a city without pervasive connectivity of all participants is likely to perform more poorly, other things equal. This is not only from the economic costs of crime, policing and incarceration, social services and the like, but a fundamental dynamic of social networks. According to what is known as Metcalfe's Law, it is not only the density of your 'rich club network,' but also the extent of the broader network that matters.

As Bettencourt (2013, p. 7) said:

The view of cities in terms of social networks emphasizes the primary role of expanding connectivity per person and of social inclusion in order for cities to realize their full socioeconomic potential. In fact, cities that for a variety of reasons (violence, segregation, lack of adequate transportation) remain only incipiently connected will typically underperform economically compared to better mixing cities... what these results emphasize is the need for social integration in huge metropolitan areas over their largest scales, not only at the local level, such as neighbourhoods.

Put differently, urban equity and environmental justice are also good for everyone's bottom line.

The emerging work in urban network science offers promising avenues for further development of a new generation of more effective tools and strategies for managing the dynamics of cities, and achieving the goals of the Charter of the New Urbanism and the New Urban Agenda. They include new and revised codes, standards, laws, governance structures, professional models, financial mechanisms, tax policies, new network-based and 
open data tools (like our own proposed 'new pattern language wiki'; Mehaffy et al., 2020) and more-in short, all of the elements of the 'operating system for growth' that generate the urban world we inhabit today, and will inhabit tomorrow.

It may be helpful to remember that the urban structures we see today, and the systems that generate them, are hardly immutable. Indeed, they have changed dramatically, and are still changing. As we once did, we have the capacity to transform them as we must again, so long as we recognize and act on that capacity. Just as we had the power to fragment and degrade cities, so now we have the power to regenerate them.

\section{Acknowledgments}

The authors are grateful to Peter Elmlund and the Ax:son Johnson Foundation for financial support of this research.

\section{Conflict of Interests}

The authors declare no conflict of interests.

\section{References}

Alexander, C. (2015). A city is not a tree. Portland, OR: Sustasis Press. (Original work published 1965)

Alexander, C., Ishikawa, S., Silverstein, M., Jacobson, M., Fiksdahl-King, I., \& Angel, S. (1977). A pattern language: Towns, buildings, construction. London: Oxford University Press.

Alexander, C., Schmidt, R., Hanson, B., Alexander, M. M., \& Mehaffy, M. (2005). Generative codes: The path to building welcoming, beautiful, sustainable neighborhoods. In T. Haas (Ed.), New urbanism and beyond: Designing cities for the future (pp. 14-29). New York, NY: Rizzoli.

Batty, M. (2013). The new science of cities. Cambridge, MA: MIT Press.

Bettencourt, L. M. A. (2013). The kind of problem a city is. Santa Fe, NM: Santa Fe Institute. Retrieved from https://sfi-edu.s3.amazonaws.com/sfi-edu/ production/uploads/sfi-com/dev/uploads/filer/fa/ f6/faf61418-fc4f-42d5-8c28-df1197a39018/13-03008.pdf

Congress for the New Urbanism. (2020). Charter of the New Urbanism. Congress for the New Urbanism. Retrieved from https://www.cnu.org/who-weare/charter-new-urbanism

Duany, A. (1997). Urban or suburban: A discussion at the GSD (Transcript of round table discussion). Harvard Design Magazine, 1997(1). Retrieved from http:// www.harvarddesignmagazine.org/issues/1

Duany, A. (2004). A conversation with Andrés Duany. Katarxis № 3. Retrieved from http://katarxis3.com/ Duany.htm

Future of Places. (2020). Speakers. Future of Places.
Retrieved from http://futureofplaces.com/speakergallery

Gold, J. R. (1998). Creating the Athens charter: CIAM and the functional city, 1933-43. Town Planning Review, 69(3), 225-247.

Haas, T. (2005). Introduction. In T. Haas (Ed.), New Urbanism and beyond: Designing cities for the future (pp. 9-13). New York, NY: Rizzoli.

Habraken, N. J. (2019). Supports: An alternative to mass housing. London: Routledge.

Holston, J. (1989). The modernist city: An anthropological critique of Brasilia. Chicago, IL: University of Chicago Press.

Jacobs, J. (1961). The death and life of great American cities. New York, NY: Random House.

Jacobs, J. (1969). The economy of cities. New York, NY: Vintage.

Katz, P. (1993). The new urbanism: Toward an architecture of community. New York, NY: McGraw-Hill Education.

Le Corbusier. (1973). The charter of Athens (A. Eardley, Trans.). New York, NY: Grossman.

Mehaffy, M. (2017). Cities alive: Jane Jacobs, Christopher Alexander and the roots of the new urban renaissance. Portland, OR: Sustasis Press.

Mehaffy, M., \& Haas, T. (2018). Engaging informality in the New Urban Agenda. Berkeley Planning Journal, 30(1).

Mehaffy, M., Kryazheva, Y., Rudd, A., Salingaros, N., Gren, A., Mouzon, S., . . Rofè, Y. (2020). A new pattern language for growing regions: Places, networks, processes. Portland, OR: Sustasis Press.

Moule, E. (2002). The charter of the New Urbanism: Introduction to The Seaside debates. New York, NY: Rizzoli.

Project for Public Spaces. (2008). Placemaking heroes: Christopher Alexander. Project for Public Spaces. Retrieved from https://www.pps.org/ article/calexander

Roche, M. P. (2019). Taking innovation to the streets: Microgeography, physical structure and innovation. Review of Economics and Statistics. Advance online publication. https://doi.org/10.1162/rest_a_00866

Sassen, S. (2010). Global inter-city networks and commodity chains: any intersections? Global Networks, 10(1), 150-163.

Sennett, R., Burdett, R., Sassen, S., \& Clos, J. (2018). The Quito papers and the New Urban Agenda. London: Routledge.

Sert, J. L. (1942). Can our cities survive? Cambridge, MA: Harvard University Press.

Talen, E. (2000). New urbanism and the culture of criticism. Urban Geography, 21(4), 318-341.

Talen, E. (2005). New urbanism and American planning: The conflict of cultures. London: Routledge.

United Nations. (2016). Resolution adopted by the General Assembly on 23 December 2016 (71/256). New York, NY: United Nations.

UN-Habitat. (2020). New Urban Agenda. UN-Habitat. 
Retrieved from https://unhabitat.org/about-us/ new-urban-agenda

van Eyck, A. (1954). Statement against rationalism (Essay presented at the 1947 CIAM Congress). In S. Giedion (Ed.), A decade of modern architecture (pp. 43-44). Zurich: Gursberger.

World Economic Forum. (2020). The New Urban Agen- da has been formally adopted. So what happens next? World Economic Forum. Retrieved from https://www.weforum.org/agenda/2016/11/lastmonth-a-new-global-agreement-to-drivesustainable-urban-development-was-reachedso-what-is-it-and-happens-next

\section{About the Authors}

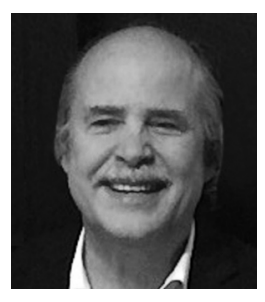

Michael W. Mehaffy (PhD) is currently a Senior Researcher with the Centre for the Future of Places at KTH Royal Institute of Technology in Stockholm. He holds a PhD in Architecture from Delft Institute of Technology and has held seven university appointments in six countries in architecture, planning, and the philosophy of design.

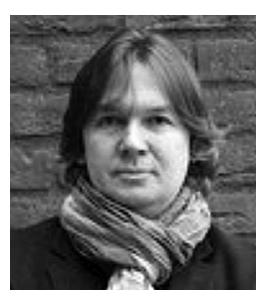

Tigran Haas (BArch/MArch, MSc, PhD) is Tenured Associate Professor, Reader of Urban Planning and Urban Design, and current Director of the Centre for the Future of Places (CFP) as well as Director of the Graduate Studies in Urbanism at the School of Architecture and the Built Environment, KTH Royal Institute of Technology, Stockholm. 